\title{
Economics of Salt-induced Land Degradation and Restoration
}

\author{
Manzoor Qadir ${ }^{a, b, c *}$ \\ Emmanuelle Quillérou $^{a}$ \\ Vinay Nangia ${ }^{b}$ \\ Ghulam Murtaza $^{d}$ \\ Murari Singh $^{b}$ \\ Richard J. Thomas ${ }^{a}$ \\ Pay Drechsel ${ }^{c}$ \\ Andrew D. Noble ${ }^{c}$
}

${ }^{a}$ United Nation University, Institute for Water, Environment and Health, 175, Longwood Road South, Hamilton, L8P 0A1, Ontario, Canada

${ }^{b}$ International Center for Agricultural Research in the Dry Areas (ICARDA), Khalid Abu Dalbouh Street, Abdoun, P.O. Box 950764, Amman, Jordan

${ }^{c}$ International Water Management Institute (IWMI), P.O. Box 2075, Colombo, Sri Lanka

${ }^{d}$ Institute of Soil and Environmental Sciences, University of Agriculture, Faisalabad 38040, Pakistan

\footnotetext{
*Corresponding author

Phone: +1-905-667-5511

Fax: +1-905-667-5510

E-mail: Manzoor.Qadir@unu.edu
} 


\title{
Economics of Salt-induced Land Degradation and Restoration
}

\begin{abstract}
Food security concerns coupled with the scarcity of new productive land have put productivity enhancement of degraded lands back on the political agenda. In such a context, salt-affected lands are a valuable resource that cannot be neglected nor easily abandoned even with their lower crop yields. This is especially true in areas where significant investments have already been made in irrigation and drainage infrastructure. A review of previous studies shows a very limited number of highly variable estimates of the costs of salt-induced land degradation combined with methodological and contextual differences. Simple extrapolation suggests that the global annual cost of salt-induced land degradation in irrigated areas could be US\$27.3 billion because of lost crop production. We present selected case studies that highlight the potential for economic and environmental benefits of 'action' to remediate saltaffected lands compared to taking 'no action'. The findings indicate that it can be cost effective to invest in sustainable land management in countries confronting salt-induced land degradation. Such investments in effective remediation of salt-affected lands should form part of a broader strategy for food security, defined in national action plans. This broader strategy is required to ensure identification and effective removal of barriers to the adoption of sustainable land management, including perverse subsidies. While reversing salt-induced land degradation would require several years, interim salinity management strategies could provide a pathway for effective remediation and further showcase the importance of reversing land degradation and rewards of investing in sustainable land management.
\end{abstract}

Key words: Sustainable land management; salinity management policies; salt-affected soils; integrated remediation strategies 
Salt-induced land degradation is common in arid and semi-arid regions where rainfall is too low to maintain a regular percolation of rainwater through the soil and irrigation is practiced without a natural or artificial drainage system. Such irrigation practices without drainage management trigger the accumulation of salts in the root zone, affecting several soil properties and crop productivity negatively. Salt-affected soils occur within the sovereign borders of at least 75 countries and occupy more than $20 \%$ of the global irrigated area (Ghassemi et al., 1995). This percentage has increased with time (Metternicht and Zinck, 2003); in some countries, salt-affected land occurs on more than half of the irrigated land.

Well known examples of salt-induced land degradation include the Aral Sea Basin (AmuDarya and Syr-Darya River Basins) in Central Asian countries, the Indo-Gangetic Basin in India, the Indus Basin in Pakistan, the Yellow River Basin in China, the Euphrates Basin in Syria and Iraq, the Murray-Darling Basin in Australia, and the San Joaquin Valley in the United States. The environmental changes resulting from salt-induced land degradation in the Aral Sea Basin are considered to be the largest caused by humanity in recent times.

It is generally recognized that a large proportion of salt-affected soils in irrigated areas occurs on land inhabited by smallholder farmers. The social and economic dimensions of saltinduced land degradation have, however, received little attention in comparison to its biophysical aspects (Zekri et al., 2010). The limited information on quantifying the social and economic impacts of such degradation reveals that most affected farmers supplement their low on-farm income with off-farm economic activities (Zekri et al., 2010) and some farmers in severely affected areas move to nearby cities for labor work (Ali et al., 2001).

With the need to provide more food, feed, and fiber to an expanding population, and little new productive land available, there will be a need to for productivity enhancement of saltaffected lands in irrigated areas (Qadir and Oster, 2004). Therefore, salt-affected lands cannot be neglected especially in areas where significant investments have already been made in irrigation and drainage infrastructure.

Based on the available literature, this paper firstly discusses how the biophysical aspects of salt-induced degradation are related to economics; secondly reports on agricultural productivity losses at farm, regional, and global scales due to salt-induced land degradation; and thirdly elaborates on the economic cost of no action (benefit loss due to salt-induced land degradation under 'business-as-usual') and the net economic benefit of action (derived from preventing and/or reversing land degradation), with a particular focus on irrigated areas.

\section{Characterization of Salt-induced Land Degradation}

A range of procedures and techniques are available to characterize salt-affected areas, from laboratory analysis of soil samples to monitoring and mapping via remotely-sensed tools 
(Rhoades, 1993; Metternicht and Zinck, 2003; Ivits et al., 2013). Salt-affected soils are generally categorized into: saline, alkali ( sodic), and saline-alkali ( saline-sodic) soils. Saline soils are characterized as non-sodic containing sufficient soluble salts to adversely affect the growth of most crop plants. Alkali ( sodic) soils are characterized by elevated levels of sodium ions and exhibit structural problems as a result of certain physical processes (slaking, swelling, and dispersion of clay) and specific conditions (surface crusting and hardsetting). With properties overlapping, saline-alkali ( saline-sodic) soils are characterized by elevated levels of soluble salts and sodium ions. Recent evidence globally has helped in characterizing magnesium-affected soils (Vyshpolsky et al., 2008). With high levels of magnesium, these soils when plowed form large clods that impede water flow resulting in poor water distribution and plant growth.

Characterization of salt-affected lands helps determine which restoration options are suitable for a given context. With saline soils, the cost of restoration usually increases with the degree of salinization (Murtaza, 2013). For example, a moderately saline soil would require less investment to bring it back to a productive state than a highly saline soil under similar conditions, although both soils fall under 'saline soil' category. Similarly, the quantity and related cost of a calcium source, such as gypsum, increase with the level of sodium in sodic soils or magnesium in magnesium-affected soils (Vyshpolsky et al., 2008).

In addition to the cost associated with minimizing salt, sodium, or magnesium levels, the costs of land restoration is driven by the presence of compacted layer in subsoil (Hassan et al., 2013), which needs to be broken to leach the salts from the root zone. Other factors affecting the cost of land restoration include the quality and quantity of water available for leaching (Murtaza, 2013); the quality and depth of groundwater (Vyshpolsky et al., 2008); the crops to be grown during and after soil amelioration and their market value (Kushiev et al., 2005; Lamers et al., 2008); the topographic features of the land (Hassan et al., 2013); and the climatic conditions as soils under hot and arid climate would need more water and time to reach a specific level of remediation than those under cold and humid climate, considering other factors constant. Most of these factors are not detailed in the economic studies of saltinduced land degradation reviewed in this paper, and the economic estimates presented may vary considerably with the specific biophysical conditions.

\section{Costs of Salt-induced Land Degradation}

The costs of land degradation are mostly estimated from crop yield losses for a range of saltaffected irrigated lands. The crop yield losses can be measured in terms of biophysical output losses (e.g. $\mathrm{t} \mathrm{ha}^{-1}$ ) and/or in monetary terms (e.g. $\$ \mathrm{ha}^{-1}$ ). In some cases, additional inputs are used to mitigate some of the impact of salt-induced land degradation that would not be used under non-degraded land, with additional costs.

The economic costs of salt-induced land degradation have been estimated in countries such as Australia, India, the United States, Iraq, Pakistan, Kazakhstan, Uzbekistan, and Spain. Many 
salinity-related economic analyses have been conducted since the 1980s in Western Australia where salinity is a prominent problem and economics is a key tool for policy assessment and implementation. Australia is also a country with many government policies and programmes aimed at better management of dryland salinity (Pannell, 2001). Operational tools such as INFFER $^{\mathrm{TM}}$ (Investment Framework for Environmental Resources) have been designed to inform the development and prioritization of projects to address environmental issues such as reduced water quality, biodiversity, and land degradation (INFFER, 2013; http://www.inffer.com.au/). Elsewhere, other approaches and tools are available for participatory natural resource management planning at landscape scale while considering land degradation and associated declining agricultural productivity (Metternicht and Zinck, 2003; Ivits et al., 2013).

Table 1 provides a summary of previous studies on the cost of salt-induced land degradation. Some of these costs correspond to a reduction in benefits derived because of salt-induced land degradation (e.g. loss of crop yield) while others correspond to additional costs (e.g. remediation of degraded land).Valuation of the cost of salt-induced land degradation mainly relies on estimating production losses. This has been done by estimating the opportunity cost of production (Singh and Singh 1995; Janmaat 2004; John et al., 2005; Wicke et al., 2011), the cost of mitigation (Madden et al., 2000, Lowell et al., 2007; Winpenny et al., 2010) or dose-response methods to estimate agricultural yield losses for various levels of salinity (Marshall and Jones 1997; Houk et al., 2006). Market prices have been considered more recently, through the establishment of a tradable permit market (Connor et al. 2008) or by considering land rents as a value proxy (Wicke et al., 2011). The transaction costs of saltmanagement policies have also been estimated in a few studies (Marshall 2004; McCann and Hafdahl 2007). Most valuation studies are based on mathematical modeling and/or statistical estimations from empirical data.

\section{Table 1: ABOUT HERE}

Estimated values of the costs of salt-induced land degradation and restoration are very heterogeneous due to different methodologies used in the assessment process, differences in soil types, the type of degradation considered as well as in general economic context. For example, different types of salt-induced land degradation are lumped together or, in several cases, not specified. In certain cases, the land degradation costs are combined with another form of land degradation, such as waterlogging. In addition, there are differences in soil parameters and criteria used to assess the intensity of salt-induced land degradation. There are also differences among the assessment studies based on geographical dimensions, timescales and variation in the levels of investment and income even within a specific region. There are a limited number of other economic factors describing the site being valued (income, site area, population, and nearby substitute sites, among others). Even agricultural factors such as cropping patterns are not always fully detailed. The overall little detail provided on the biophysical, geographic and economic factors that could influence estimates in all these 
studies impair the possibility to derive statistically meaningful estimates through regression analysis, or derive a reliable estimate through benefit transfer.

The general lack of studies, methodological limitations and result heterogeneity also make it difficult to judge the reliability and validity of the estimates available. However, the validity of the estimates from the report by Madden et al. (2000) may be questionable. This report is a commissioned commercial consultancy funded on behalf of the Australian Conservation Foundation and the National Farmers Federation. Both of these groups, at the time, were in alliance and seeking grants from the Australian Government's then-existing salinity program. Because of this, we can suspect the costs of action to be overestimated, especially when compared to estimates from other studies such as the global estimates that can be derived from Ghassemi et al. (1995), or estimated for the whole of Australia (Wilson, 2003).

\subsection{Productivity Losses from Salt-affected Lands at Farm Level}

Farm-level studies mostly measure the costs in terms of their impact on physical output losses. In the Indo-Gangetic Basin in India, the crop yield losses on salt-affected lands for wheat, rice, sugarcane and cotton grown on salt-affected lands could be $40 \%, 45 \%, 48 \%$, and $63 \%$, respectively (Table 2). In addition, employment losses could be 50 to 80 man-days ha ${ }^{-1}$ along with $20-40 \%$ increase in human health problems and $15-50 \%$ increase in animal health problems (Tripathi, 2009).

\section{Table 2: ABOUT HERE}

Multi-location studies undertaken on saline-sodic fields in the Indus Basin in Pakistan comparing agricultural produce from salt-affected lands reveal wheat grain yield losses from salt-affected lands ranged between $20 \%$ and $43 \%$ with an overall average loss of $32 \%$. For rice, the crop yield losses from salt-affected lands ranged from 36\% to $69 \%$ with an overall average loss of $48 \%$ (Murtaza, 2013); rice yield losses were higher than those of wheat.

The Tungabhadra Project in south-west India is a protective irrigation system, which has been designed to provide limited supplemental irrigation over a large area. While investigating the cost of irrigation-induced land salinization in the Tungabhadra Project area, Janmaat (2004) reported the economic cost varying from 15 to $37 \%$ of the productivity potential. Inefficient water distribution and on-farm water management were major contributors to land salinization and low system performance in the project area.

Studies undertaken on magnesium-affected soils in southern Kazakhstan (Aral Sea Basin) reveal $71-86 \%$ farm productivity losses from these soils when compared to magnesiumaffected soils ameliorated by the application of phosphogypsum in the same area (Vyshpolsky et al., 2008). Elsewhere in Europe, the data suggests significant farm productivity losses due to salinity and sodicity problems in soils when compared with those soils without such problems under similar agro-climatic conditions (Ivits et al., 2013). 


\subsection{Costs of Salt-induced Land Degradation at River Basin and Global Levels}

Studies on the annual economic cost of salt-induced land degradation under irrigated agriculture at the regional and river basin scales reveal US\$ ${ }^{1} 267$ million in the Indus Basin (Aslam and Prathapar, 2006), \$249 million in the Murray-Darling Basin (Wilson, 2003), \$750 million in the Colorado River Basin (Ghassemi et al., 1995), and \$2.7 billion in the AmuDarya and Syr-Darya Basins (World Bank, 1998).

At a global scale, Ghassemi et al. (1995) reported annual income losses from salt-affected irrigated areas around \$12 billion based mainly on crop yield losses. They reported 45.4 million ha irrigated area as salt-affected, i.e. 20\% of the global irrigated area in 1990 (227 million ha). Based on this estimate, the annual cost of salt-induced land degradation was approximately $\$ 264 \mathrm{ha}^{-1}$ in 1990 . Since this assessment, there has been an increase in the extent of irrigated area vis-à-vis salt-induced land degradation. In 2002, the global irrigated area was estimated at 277 million ha. Considering 20\% of this area affected by salts (55.4 million ha) and the same cost of land degradation valued in 1990 ( $\$ 264 \mathrm{ha}^{-1}$ ), the annual economic losses in 2002 were \$14.6 billion. Adjusting for \$ inflation during the 1990-2002 period, the cost of salt-induced land degradation in 2002 was $\$ 345 \mathrm{ha}^{-1}$ with global losses of $\$ 19.1$ billion (Figure 1). Considering current extent of global irrigated area as 310 million ha (FAO-AQUASTAT, 2013) and 20\% of this area as salt-affected (62 million ha) and the inflation-adjusted cost of salt-induced land degradation in 2013 as $\$ 441 \mathrm{ha}^{-1}$, a simple benefit transfer suggests the current annual economic losses could be $\$ 27.3$ billion (Figure 1).

\section{Figure 1: ABOUT HERE}

It is important to note that the above numbers on global cost of salt-induced land degradation refer to economic losses based on crop yield losses only. However, the crop yields from irrigated areas not affected by salinization have increased since 1990 due to improved crop varieties, efficient on-farm practices, better fertilizer use, and efficient water management practices, among others. Consequently, there may be larger gaps in crop yields harvested from salt-affected and non-affected areas under similar agro-ecosystems, suggesting underestimation of the economic cost of salt-induced land degradation. These costs are expected to be even higher when other cost components such as infrastructure deterioration (including roads, railways, and buildings), losses on property values of farms with degraded land, and the social cost of farm businesses are taken into consideration. In addition, there could be additional environmental costs associated with salt-affected degraded lands as these lands emit more greenhouse gases thus contributing to global warming (Ivits et al., 2013).

\footnotetext{
${ }^{1}$ Unless otherwise specified, \$ refers to 2013 US dollars (US\$) throughout this publication. See footnote to Table 1 for more details.
} 


\section{$4 \quad$ Benefits from Reversing the Land Degradation Trend}

Limited studies have been undertaken on the comparative evaluation of the economics of 'no action' and 'action' with regard to salt-affected lands. For the results presented below, the benefits from reversing the trends in land degradation by different options were calculated as the difference between the net benefit under 'action' and net benefit under 'no action' systems. The net benefits under both systems were calculated as total benefit minus total cost. The total cost under 'no action' included (1) cultivation and production cost (seed and seedbed preparation, use of farm equipment and fuel, insecticides, pesticides, and herbicides, where needed); (2) fertilizer cost (purchase, transport, and application of fertilizer); (3) labor cost (plowing and sowing, field operation and cleaning, harvesting, and post-harvest management); and (4) irrigation cost (delivery and cost of irrigation water, pumping cost where applicable). The total benefit under 'no action' included gross income from the farm produce in terms of sale in the market and/or on-farm utilization. The same approach was used under 'action', except another cost element was added, which referred to the cost of land restoration or reversing land degradation (cost of additional water to be used for leaching salts from root zone; cost of physical work such as land leveling, deep plowing or sub-soiling, where needed; purchase and application of soil amendment, if needed; and any other related expenditure). This approach included by design the cost of additional inputs used to mitigate the impact of land degradation on farm yields.

Although the economics of salt-induced land degradation and restoration is based on related benefits and costs as explained in the above paragraph, there are additional benefits stemming from ecosystem services resulting from the restoration of degraded lands, such as carbon sequestration; recreation and aesthetic values; and reduction in environmental degradation through improvements in soil health and structure, surface and groundwater quality, and air quality. Valuation of such ecosystem services is expected to result in favorable environmental and economic benefits, although functional markets for many of the ecosystem services are currently embryonic or nonexistent.

\subsection{Phosphogypsum for Productivity Enhancement of Magnesium-affected Lands}

In a farmers' participatory study, Vyshpolsky et al. (2008) used phosphogypsum (PG) to ameliorate magnesium-affected soils, which cover more than $30 \%$ of the irrigated area in southern Kazakhstan. They used three treatments with four replications: (1) control (no PG application), (2) PG application at $4.5 \mathrm{t} \mathrm{ha}^{-1}$ and (3) PG application at $8.0 \mathrm{t} \mathrm{ha}^{-1}$. The PG application increased calcium concentration in the soil, which triggered the replacement of excess magnesium from the soil's cation exchange sites causing significant decrease in exchangeable magnesium percentage (EMP) of the soil over the pre-study EMP levels. The 4year average cotton yields were $2.6 \mathrm{t} \mathrm{ha}^{-1}$ with $8 \mathrm{t} \mathrm{PG} \mathrm{ha}^{-1}, 2.4 \mathrm{tha}^{-1}$ with $4.5 \mathrm{t} \mathrm{PG} \mathrm{ha}{ }^{-1}$, and $1.4 \mathrm{t} \mathrm{ha}^{-1}$ in the control. The net income from PG application at $4.5 \mathrm{t} \mathrm{ha}^{-1}\left(\$ 522 \mathrm{ha}^{-1}\right)$ and $8.0 \mathrm{t}$ $\mathrm{ha}^{-1}\left(\$ 554 \mathrm{ha}^{-1}\right)$ was double than that from the control $\left(\$ 241 \mathrm{ha}^{-1}\right)$. For PG treatments, additional economic gains $\left(\$ 32 \mathrm{ha}^{-1}\right)$ from the higher application rate of PG (8 $\mathrm{tha}^{-1}$ ) were 
marginal; suggesting that the lower rate of PG was optimal (Figure 2). Since PG was applied once at the beginning, EMP levels tended to increase four years after its application as all the calcium from the amendment was gradually utilized in the amelioration process. This trend suggested the need for reapplication of PG to such soils after every 4-5 years to sustain higher levels of cotton production.

\section{Figure 2: ABOUT HERE}

With more farmers using PG in the study area, it is now considered a potential option for the farmers to become more independent from the local cotton pricing system, which is largely influenced by private cotton trading companies. Most cotton growers in the area and cotton companies establish contracts on the 'future price' of cotton, which is usually predetermined by both parties. Farmers take loans from the companies to meet the costs of farm inputs and operations with an agreement to pay back the loan at crop harvest time. Such agreements benefit the companies because the cotton 'future price' is always kept lower than the actual market price and farmers are bound to sell the cotton to the contracted companies. Therefore, under 'no action' situation, low cotton productivity from degraded lands just helps farmers in paying off the loan they take at the beginning of the season, thereby ending up in very small profits. With PG application leading to higher profits, farmers have the opportunity to produce more cotton and become more independent by selling cotton in open markets.

\subsection{Phytoremediation of Highly Saline Abandoned Lands}

In the Hungary Steppes in Uzbekistan, restoration of highly saline abandoned soils was undertaken by using licorice (Glycyrrhiza glabra), a salt-tolerant perennial shrub species, as phytoremediation crop (Kushiev et al., 2005). Licorice can grow to a height of $1.5 \mathrm{~m}$ and has a fusiform root system with numerous suckers that often grow more than $1 \mathrm{~m}$ deep and help in lowering the shallow groundwater level. The roots of licorice are in high demand due to three main reasons: (1) sweeter in taste and may be chewed or eaten as a sweet, making it a useful component of candies and sweets; (2) reputed medicinal qualities; and (3) glycyrrhizic acid can be extracted and used as a flavoring in agent food, tobacco, alcohol, and cosmetics.

Licorice was grown on 13 ha that had been abandoned due to high levels of salts and shallow groundwater. An adjacent field of 10 ha was left as such during the study period, 1999-2003. The first crop of licorice fodder was harvested in 2001 and yielded dry matter at $3.6 \mathrm{t} \mathrm{ha}^{-1}$ with a protein content of $12 \%$. By 2003, licorice fodder and root yields were progressively increased and reached $5.1 \mathrm{t} \mathrm{ha}^{-1}$ and $8.5 \mathrm{t} \mathrm{ha}^{-1}$, respectively.

At the end of the 2003 growing season, the control and licorice grown fields were prepared for wheat-cotton rotation. Wheat yield was $2.42 \mathrm{t} \mathrm{ha}^{-1}$ after licorice cultivation and $0.87 \mathrm{t} \mathrm{ha}^{-1}$ from the control plots. Similarly, soil remediation effects of licorice caused an increase in cotton yield from $0.31 \mathrm{t} \mathrm{ha}^{-1}$ to $1.89 \mathrm{t} \mathrm{ha}^{-1}$. With average yields of wheat and cotton in the study area as 1.75 and $1.5 \mathrm{t} \mathrm{ha}^{-1}$, respectively, licorice demonstrated the potential to increase 
productivity and farm-level income from abandoned saline fields. This was attributed to a combination of lowering of water table, enhanced leaching of salts associated with improved hydraulic conductivity, and increase in soil organic carbon content (Kushiev et al., 2005). These biophysical indicators would need to be supplemented by a cost-benefit analysis over the life time of the remediation projects. This data was however not available for this study.

While phytoremediation through licorice seems promising, there are associated trade-offs. It is important to note that phytoremediation does not negate the role of functional drainage system for improved management of salinity in the long run. Phytoremediation, however, offers an interim measure on the path to effective salinity management. There are implications associated with the introduction of licorice in the remediation process as it is an invasive weedy species. Its extensive root system with the ability to develop sucker makes this species difficult to control without the use of herbicides, i.e. additional cost.

\subsection{Plantation of Multipurpose Tree Species on Saline Wastelands}

Lamers et al. (2008) evaluated the prospects of establishing agroforestry systems on saline wastelands in the lower reaches of Amu-Darya River in Uzbekistan. They collected biomass data of three tree species (Elaeagnus angustifolia, Ulmus pumila, and Populus euphratica) for four years and complemented this with data of mature trees (15-20 years) growing naturally on the marginal land. The potential for capital investment in small-scale woodlots was assessed by considering annual fuelwood, fodder and fruit production, plus the stumpage value after 20 years. The benefit to cost ratio (BCR) and Net Present Value (NPV) were compared at $10 \%, 16 \%$ and $24 \%$ discount rates. At $16 \%$ discount rate, the NPV for Elaeagnus angustifolia was greatest $\left(\$ 13,924 \mathrm{ha}^{-1}\right)$, followed by Populus euphratica $\left(\$ 4,096 \mathrm{ha}^{-1}\right)$, and Ulmus pumila $\left(\$ 1,717 \mathrm{ha}^{-1}\right)$ showing a BCR of 7.8, 2.2 and 1.8 for these species, respectively.

This study demonstrated that tree plantations may provide positive returns to investment and significant economic and social benefits to land users. These findings suggest that there is an opportunity for capital investment in afforesting abandoned salt-affected lands with multipurpose tree species. Although the financial assessment of afforestation is an important criterion, many additional factors such as risk assessment, familiarity with techniques to raise tree plantations, and the availability of technical support would influence the decision-making process of farmers in establishing agroforestry systems on wastelands.

Fuelwood prices are expected to rise in the study area owing to ever-increasing energy prices and the growing dependency on firewood. Therefore, an aggressive campaign would motivate farmers and investors to integrate ecologically appropriate tree production systems on saline wastelands. Such an approach would require an enabling political will and institutional awareness. In addition, forestry policies must be reoriented and aligned to involve rural and urban users relying on trees for part of their income and/or domestic needs. 


\subsection{Use of Amendments to Ameliorate Saline-sodic Lands}

In a recent study in Pakistan, Murtaza (2013) synthesized data from 8 salt-affected areas in the Indus Basin. Rice and wheat were grown in rotation on ameliorated and degraded lands characterized as calcareous saline-sodic lands. Gypsum, farm manure, sulfuric acid, and rice husk were used as soil ameliorants. In the fields grown with rice, soil salinity (electrical conductivity, EC) was in the range of 6.0 to $12.5 \mathrm{dS} \mathrm{m}^{-1}$ and soil sodicity (sodium adsorption ration, SAR) ranged from 25.0 to 44.5. Post-amelioration soil EC at these locations ranged from 3.0 to $3.9 \mathrm{dS} \mathrm{m}^{-1}$ while soil SAR varied from 9.7 to 12.5 . In the plots in the wheat phase of the crop rotation, soil EC in the salt-affected fields was 4.7 to $9.2 \mathrm{dS} \mathrm{m}^{-1}$ while soil SAR was 19.1 to 26.1. The soil EC in the ameliorated fields at these locations was 2.9 to $3.9 \mathrm{dS} \mathrm{m}^{-1}$ while soil SAR varied from 9.8 to 12.0 .

There were significantly higher economic returns from ameliorated fields compared with saltaffected fields $(p<0.05)$. The average net income from rice grown on salt-affected fields $\left(\$ 427 \mathrm{ha}^{-1}\right.$ ) was significantly lower than ameliorated fields $\left(\$ 825 \mathrm{ha}^{-1}\right)$, suggesting that the action (soil amelioration) doubled the net income (Table 3). In case of wheat, the average net income from salt-affected fields ( $\$ 771 \mathrm{ha}^{-1}$ ) increased to $\$ 1115 \mathrm{ha}^{-1}$ from ameliorated fields, i.e. additional profit of $\$ 344$ from the ameliorated land. Association between soil parameters and income for ameliorated land indicated statistically significantly negative correlation between soil EC and respective income level ( $r=-0.75 ; p=0.003)$. The correlation between soil SAR and respective income levels was non-significant, although the expected negative trend was observed numerically between soil SAR and net profit.

\section{Table 3: ABOUT HERE}

\subsection{Salinity Management through Physical and Crop-based Options}

In a farmers’ participatory study in the Euphrates Basin in Iraq, Hassan et al., (2013) used cost-benefit analysis of adopting different salinity management practices versus control (no action). The study site was located in semi-arid area with annual average minimum and maximum temperatures of 15.4 and $30.1{ }^{\circ} \mathrm{C}$, respectively. The soils are medium textured, poorly drained, and moderately saline (EC $10-20 \mathrm{dS} \mathrm{m}^{-1}$ ). The annual cumulative rainfall is $141 \mathrm{~mm}$ and irrigation water (EC 1.0-1.3 dS $\mathrm{m}^{-1}$ ) is required to grow crops. The farmers selected were those using good practices and those without such practices (control).

Four practices (deep plowing, crop rotation, mixing residues, and digging drains) were used along with their respective control treatments. Deep plowing was used to break the hardpan below the plow layer. Crop rotations involved cultivation of salt-tolerant varieties of wheat followed by legumes such as mung bean. Mixing of harvested plant residues with the topsoil was carried out using a moldboard plow. Digging a drain or deep ditch around the saltaffected land was done to facilitate land drainage. 
The results demonstrated significant $(\mathrm{p}<0.001)$ reduction in soil EC after the application of good practices as well as income and profit by the application of these best-bet practices over their respective control treatments (Table 4). The profits from the four best-bet practices followed the following pattern: crop rotation $\left(\$ 2,243 \mathrm{ha}^{-1}\right)$, digging drain $\left(\$ 1,193 \mathrm{ha}^{-1}\right)$, mixing residue $\left(\$ 1,057 \mathrm{ha}^{-1}\right)$, and deep plowing $\left(\$ 646 \mathrm{ha}^{-1}\right)$.

\section{Table 4: ABOUT HERE}

\section{$5 \quad$ Managing Variations in Economics of Land Degradation and Restoration}

In a limited data environment, dose-response models (models that link a level of crop yield to a level of salt-induced land degradation) could be used to estimate the costs of salt-induced land degradation. Such production loss models can be established using regression analysis to determine the dose-response function, i.e. how crop yields vary as a function of salt levels in growth medium (Houk et al., 2006), taking salt thresholds into account, and the need to be recalibrated to the specific sites to be valued. The farm level costs (loss of benefits) of saltinduced land degradation can be estimated by multiplying the yield lost because of land degradation by the market price of agricultural crops grown. They would need to be compared to the cost of land restoration for decision-making on whether to restore or not.

The production loss models could be further combined, data and capacity allowing, to hydrological and economic models for more accurate estimates. Salt-induced land degradation can impact other economic activities beyond agriculture, and these would ideally need to be taken into account. Alternatively, when soil is not suitable for agricultural production because of high salt levels and associated cost of restoration prohibitively greater than a farmer can afford, other economic activities can be established to mitigate the economic impact of salt-induced land degradation such as eco-tourism. There exist economic valuation methods other than production loss models that can, when relevant, help estimate the potential benefits to be derived from these new non-agricultural activities. These are reviewed in Quillérou and Thomas (2012) and ELD Initiative Interim Report (http://www.eldinitiative.org/).

\section{Conclusions and Future Perspectives}

With wide range of revenue losses, the costs of 'no action' on salt-affected lands may result in $15 \%$ to $69 \%$ losses depending on the crop grown, land degradation type and its intensity, irrigation water quality, provision and capacity of drainage system, and water distribution and on-farm soil and water management. There are other cost implications such as employment losses, increase in human and animal health problems and treatment costs, infrastructure deterioration (including roads, railways, and buildings), losses on property values of farms with degraded land, and the social cost of farm businesses. In addition, there could be associated environmental costs as these lands emit more carbon thus contribute to global warming. Therefore, the cost of salt-induced land degradation at different scales is expected to 
be even higher when the above-mentioned cost components are taken into consideration and comprehensive economic analyses are performed. Although there is a cost of investing in preventing land degradation, reversing land degradation, or restoring degraded land into productive land, our review shows that these costs of action are likely to be much less than letting land degradation continue and intensify.

The case studies reported highlight the benefits of 'action' over 'no action' expressed through the improvement in biophysical terms (soil properties) as well as economic dimensions (increase in income per unit area). A few conditions for successful land restoration identified vary depending on whether land is already under production, but productivity is low (case studies 4.1, 4.4, and 4.5), or abandoned wasteland (case studies 4.2 and 4.3). For the lowproductivity systems, there would be a need for improvement in (1) input market access such as soil amendment, farm equipment, and improved/salt-tolerant varieties of the crops; (2) infrastructure such as irrigation and drainage network; (3) input financing mechanism conditions such as loans; and (4) existing output market to absorb the increased farm produce from restored lands. For wastelands with no crop productivity, there would be a need for (1) establishment of input market access such as seeds or seedlings of salt-tolerant shrubs and tree species, and soil amendment and farm equipment, if needed; (2) repair of the abandoned irrigation and drainage network; (3) improvement in input financing mechanism conditions such as loans; and (4) establishment of new output market or linking with external markets for the farm produce uncommon in the area.

Although the case studies presented make a case for directing future investments in sustainable land management, agricultural productivity and income from salt-affected lands through site-specific management practices can only be sustainable if there is consideration in parallel for (1) pertinent policies to facilitate availability, price control, transportation, and application of soil amendments along with allocation and supply of additional amount of water for salt removal from affected areas; (2) involvement of supportive institutions and skilled human resources to undertake soil and water quality testing and mapping in the degraded areas and advice on selecting pertinent soil management approaches; (3) provision of facilities and infrastructure for disposal of salts removed from salt-affected lands during restoration; (4) capacity development of farmers to follow up on recommended salinity management approaches; and (5) utilization of locally available resources and indigenous knowledge of communities in combating salt-induced land degradation.

Since salt-induced land degradation occurs both 'on-site' and 'off-site' and affects the livelihoods within and outside the farming communities, there would be a need for thinking and acting beyond typical farm-level salinity management. This could be achieved through developing national action plans, such as National Salinity Management Strategy, drawing from a broad range of disciplines to ensure effective removal of barriers for adoption of sustainable land management and realize potential crop productivity gains. These national action plans should take into account the biophysical aspects of affected areas, socioeconomic situation of the associated communities, availability and cost of equipment and soil 
amendments, availability of skilled professionals, and relevant institutional arrangements and supportive policies. In addition, because of the prominent role of irrigation and drainage in salinity management, such action plans should also consider water politics and policies particularly in case of water availability and quality through transboundary rivers, land-use options and strategy including specific commitments to long-term renting of land to third parties or other countries, national bioenergy production strategy, markets for salt-tolerant crops and halophytes, potential economic gains from sustainable land management, and national climate change management strategy.

Salt-induced land degradation may also affect the business sector negatively either directly or indirectly, targeting their inputs, outputs, or processes. For example, reduction in productivity and availability of raw material and utilities used in industry, limited options for diversification of inputs and processes, workforce availability and business operations, product quality and brand reputation with associated loss of profit, and implications for further investments and expansion. Among the businesses potentially at greater risk are those in close connection with natural resources and are likely to experience significant effects directly or indirectly. These businesses may deal with basic resources (forestry, wood, pulp, and paper), food and beverage, construction and materials, industrial goods and services (transportation and packaging), utilities (water and electricity), personal and household goods (clothing, footwear, and furniture), leisure and travel (hotels and restaurants), and real state (Pöyry, 2013). Therefore, reversing salt-induced land degradation would help these sectors achieve potential economic gains by providing needed levels of materials and services. These sectors in return would be able to function properly to produce products and provide services for existing and new markets, and enhance brand and image goodwill along with additional manpower employment. To achieve this, there would be a need for the involvement of relevant stakeholders such as farmers, private sector (local businesses, industrial suppliers, brand owners, and marketing agencies), and public institutions (research and extension institutions, land survey and classification units, irrigation and drainage departments, and government offices). In addition, the political will and supportive policies would be the key to make this happen.

Considering the fact that land is not a fast-moving good or service and salt-affected degraded lands are an underperforming asset, the time horizon for reversing the degradation trend and restoring degraded lands may be several years. There would be a need for short- to long-term strategies to showcase the importance and awareness of reversing salt-induced land degradation. By providing pathways for effective remediation of salt-affected lands, the interim salinity management strategies could be scaling up of the promising salinity management approaches from the farm to landscape level. The Economics of Land Degradation (ELD) Initiative (http://www.eld-initiative.org/) could be an excellent platform to better value the cost of land degradation and identify relevant options and pathways for action. Led by a multi-partner consortium, the ELD Initiative is dedicated to raising global awareness of the economic potential of land and land services and the rewards of investing in sustainable land management. This initiative is focused on creating efficient and practical 
tools and methodologies to fully assess lands value and thus encourage sustainable land management practices and policies.

\section{Acknowledgments}

We gratefully acknowledge the helpful comments from three anonymous reviewers who made several excellent suggestions, which helped improve the content and presentation of this manuscript. 


\section{References}

Ali, A.M., Van Leeuwen, H.H., Koopmans, R.K., 2001. Benefits of draining agricultural land in Egypt: Results of five years monitoring of drainage effects and impacts. Water Resources Development 17: 633-646.

Aslam, M., Prathapar, S.A., 2006. Strategies to Mitigate Secondary Salinization in the Indus Basin of Pakistan: A Selective Review. Research Report 97. IWMI, Colombo, Sri Lanka.

Australian Bureau of Statistics. Agricultural Census of Western Australia: Local Government Area Data. Canberra: Australian Bureau of Statistics..

Connor, J. D., Ward, J., Clifton, C., Proctor, W., Hatton MacDonald, D., 2008. Designing, testing and implementing a trial dryland salinity credit trade scheme. Ecological Economics 67: 574-588.

ERM, 1998. National Environmental Action Plan for the Arab Republic of Syria (Chapter 5), World Bank/UNDP.

FAO-AQUASTAT., 2013. Area equipped for irrigation and percentage of cultivated land. Available at http://www.fao.org/nr/water/aquastat/globalmaps/index.stm [Accessed on 16 September 2013]

Fiorillo, C., Vercueil, J., 2003. Syrian Agriculture at the Crossroads. FAO Agricultural and Economic Development Series. Rome, Policy Assistance Division, FAO: 421.

Ghassemi, F., Jakeman, A.J., Nix, H.A., 1995. Salinisation of Land and Water Resources: Human Causes, Extent, Management and Case Studies. CABI Publishing: Wallingford.

Hassan, A.K., Nangia, V., Singh, M., 2013. Soil salinity management in Iraq using indigenous soil management techniques - analysis of biophysical and socioeconomic data. Paper presented at the ASA-CSSA-SSSA Annual International Meeting, November 3-6, Tampa, FL, USA.

Houk, E., Frasier, M., Schuck, E., 2006. The agricultural impacts of irrigation induced waterlogging and soil salinity in the Arkansas Basin. Agricultural Water Management 85: 175-183.

INFFER. 2013. Investment Framework for Environmental Resources. Available at http://www.inffer.com.au/ [Accessed on 16 September 2013]

Ivits, E., Cherlet, M., Töth, T., Lewinska, K.E., Töth, G., 2013. Characterisation of productivity limitation of salt-affected lands in different climatic regions of Europe using remote sensing derived productivity indicators. Land Degradation and Development 24: 438-452.

John, M., Pannell, D., Kingwell, R., 2005. Climate Change and the Economics of Farm Management in the Face of Land Degradation: Dryland Salinity in Western Australia. Canadian Journal of Agricultural Economics 53: 443-459.

Janmaat, J., 2004. Calculating the cost of irrigation induced soil salinisation in the tungabhadra project. Agricultural Economics 31: 81-96.

Kingwell, R. S. 1994. Risk attitude and dryland farm management. Agricultural Systems 45: 191-203.

Kingwell R. S., D. J. Pannell and S. Robinson 1993. Tactical responses to seasonal conditions in whole-farm palnning in Western Australia. Agricultural Economics 8: 211-26

Kushiev, H., Noble, A.D., Abdullaev, I., Toshbekov, U., 2005. Remediation of abandoned saline soils using Glycyrrhiza glabra: A study from the Hungry Steppes of Central Asia. International Journal of Agricultural Sustainability 3: 103-113.

Lamers, J.P.A., Bobojonov, I., Khamzina, A., Franz, J., 2008. Financial analysis of small-scale forests in the Amu Darya Lowlands of rural Uzbekistan. Forests, Trees and Livelihoods 18: 373-386.

Lowell, K., Drohan, J., Hajek, C., Beverly, C., Lee, M., 2007. A science-driven market-based instrument for determining the cost of environmental services: A comparison of two catchments in Australia. Ecological Economics 64: 61-69.

Madden, B., Hayes, G., Duggan, K., 2000. National Investment in Rural Landscapes: An Investment Scenario for NFF and ACF with the assistance of LWRRDC. Prepared for the Australian Conservation Foundation National Farmers Federation, The Virtual Consulting Group \& Griffin nrm Pty Ltd: 46.

Marshall, G.R., 2004. From words to deeds: enforcing farmers' conservation cost-sharing commitments. Journal of Rural Studies 20(2): 157-167. 
Marshall, G.R., Jones R.E., 1997. Significance of supply response for estimating agricultural costs of soil salinity. Agricultural Systems 53: 231-252.

McCann, L.M.J., Hafdahl, A.R., 2007. Agency perceptions of alternative salinity policies: The role of fairness. Land Economics 83: 331-352.

Metternicht, G.I., Zinck, J.A., 2003. Remote sensing of soil salinity: Potentials and constraints. Remote Sensing of Environment 85: 1-20.

Murray Irrigation Ltd. (MIL), 1998. Environment Report 1997/98. Murray Irrigation, Deniliquin, Australia.

Murtaza, G., 2013. Economic aspects of growing rice and wheat crops on salt-affected soils in the Indus Basin of Pakistan (unpublished data). Institute of Soil and Environmental Sciences, University of Agriculture, Faisalabad, Pakistan.

Oster, J.D., Wichelns, D., 2003. Economic and agronomic strategies to achieve sustainable irrigation. Irrigation Science 22: 107-120.

Pannell, D.J., 2001. Dryland salinity: economic, scientific, social and policy dimensions. Australian Journal of Agricultural and Resource Economics 45: 517-546.

Pöyry. 2013. Opportunity Lost: Mitigating risk and making the most of your land assets; An assessment of the exposure of business to land degradation risk and the opportunities inherent in sustainable land management. Final Report (30 June 2013) Pöyry International Consulting and Engineering. Available at http://www.bonn-perspectives.de/en/dialogue-events/land_for_business/background.html

Qadir, M., Oster, J.D., 2004. Crop and irrigation management strategies for saline-sodic soils and waters aimed at environmentally sustainable agriculture. Science of the Total Environment 323: 1-19.

Qadir, M., Noble, A.D., Schubert, S., Thomas, R.J., Arslan, A., 2006. Sodicity-induced land degradation and its sustainable management: problems and prospects. Land Degradation \& Development 17: 661-676.

Quillérou, E.; Thomas, R.J., 2012. Costs of land degradation and benefits of land restoration: A review of valuation methods and their application. CAB Reviews: Perspectives in Agriculture, Veterinary Science, Nutrition and Natural Resources 7(060): 1-12.

Rhoades J.D., 1993. Electrical conductivity methods for measuring and mapping soil salinity. Advances in Agronomy 49: 201-251.

Singh, J., Singh, J.P., 1995. Land degradation and economic sustainability. Ecological Economics 15: 77-86.

Tripathi, R.S., 2009 Alkali Land Reclamation, Mittal Publications, New Delhi.

Vyshpolsky, F., Qadir, M., Karimov, A., Mukhamedjanov, K., Bekbaev, U., Paroda, R., Aw-Hassan, A., Karajeh, F., 2008. Enhancing the productivity of high-magnesium soil and water resources through the application of phosphogypsum in Central Asia. Land Degradation \& Development 19: 45-56.

Wicke, B., Smeets, E., Dornburg, V., Vashev, B., Gaiser, T., Turkenburg, W., Faaij, A., 2011. The global technical and economic potential of bioenergy from salt-affected soils. Energy \& Environmental Science 4: 2669-2681.

Wilson, S.M., 2003. Determining the full costs of dryland salinity across the Murray-Darling Basin: Final Project Report, a Wilson Land Management Services report to the Murray-Darling Basin Commission and National Dryland Salinity Program. Available at http://www.environment.nsw.gov.au/salinity/basics/costs.htm [Accessed on 14 November 2012]

Winpenny, J., Heinz, I., Koo-Oshima, S., 2010. The wealth of waste: The economics of wastewater use in agriculture. Food and Agriculture Organization of the United Nations; 142 pages.

World Bank, 1998. Aral Sea Basin Program (Kazakhstan, Kyrgyz Republic, Tajikistan, Turkmenistan, and Uzbekistan) - Water and Environment Management Project. Project Document. Washington DC, USA, Global Environment Division, World Bank, 55 pages.

Zekri, S., Al-Rawahy, S.A., Naifer, A., 2010. Socio-economic considerations of salinity: Descriptive statistics of the Batinah sampled farms. In: Mushtaque, A., Al-Rawahi, S.A., Hussain, N (eds.) Monograph on Management of Salt-Affected Soils and Water for Sustainable Agriculture; Sultan Qaboos University, pp 99-113. 
Table 1 Review of the economic costs of salt-induced land degradation in different parts of the world

\begin{tabular}{|c|c|c|c|c|c|c|c|c|c|c|}
\hline Study by & Where & Study area & $\begin{array}{c}\text { Sampling } \\
\text { and sample } \\
\text { size }\end{array}$ & $\begin{array}{c}\text { Year of } \\
\text { estimate }\end{array}$ & $\begin{array}{c}\text { Type of } \\
\text { land } \\
\text { degradation }\end{array}$ & Crop & Valuation method & $\begin{array}{l}\text { Reported value } \\
\text { (Local currency) }\end{array}$ & $\begin{array}{c}\text { Equivalent \$ } \\
\text { (As of reporting } \\
\text { year) }\end{array}$ & $\begin{array}{c}\text { Equivalent \$ } \\
\text { (Year of } \\
\text { reference: 2013) }\end{array}$ \\
\hline \multicolumn{11}{|c|}{ Spatial aggregates } \\
\hline $\begin{array}{l}\text { Marshall } \\
\text { and Jones } \\
(1997)\end{array}$ & Australia & $\begin{array}{l}\text { Murrumbidgee } \\
\text { Irrigation Area } \\
\text { (Southeast } \\
\text { inland } \\
\text { Australia) }\end{array}$ & $\begin{array}{l}477 \text { farms } \\
(110,950 \mathrm{ha}) \\
\text { with } \\
\text { aggregate } \\
\text { irrigation } \\
\text { allocation of } \\
660,945 \mathrm{ML} \\
(1 \mathrm{ML}= \\
\left.1000 \mathrm{~m}^{3}\right)\end{array}$ & $\begin{array}{l}1993- \\
2023 \\
(1993 \\
\text { assumed } \\
\text { as year of } \\
\text { monetary } \\
\text { values) }\end{array}$ & Salinity & $\begin{array}{l}\text { Mostly } \\
\text { rice and } \\
\text { wheat }\end{array}$ & $\begin{array}{l}\text { Opportunity costs based on dose response } \\
\text { method and taking mitigation behavior into } \\
\text { account. Opportunity costs (forgone } \\
\text { agricultural income): Scenario-based bio- } \\
\text { economic modeling of loss of economic } \\
\text { surplus because of land salinization (measured } \\
\text { as the reduction in district net farm income } \\
\text { between the without and the with salinity } \\
\text { scenarios). Dose-response method: } \\
\text { yield/salinity equation for each enterprise } \\
\text { used. Mitigation behavior: allowed farmer } \\
\text { response to salinization through enterprise } \\
\text { substitution (change of crops) }\end{array}$ & $\begin{array}{l}\text { Economic surplus } \\
\text { loss of A } \$ 24.3 \\
\text { million over } 30 \text { years } \\
\text { (valued in } 1993 \\
\text { currency), ranging } \\
\text { from A } \$ 15.0 \text { million } \\
\text { to A } \$ 113.4 \text { million } \\
\text { depending on the } \\
\text { delay for farmers' } \\
\text { response to } \\
\text { salinization of their } \\
\text { land }\end{array}$ & $\$ 17$ million$/ 30 \mathrm{yr}$ & $\$ 25$ million$/ 30 \mathrm{yr}$ \\
\hline \multirow[t]{2}{*}{$\begin{array}{l}\text { Janmaat } \\
\text { (2004) }\end{array}$} & \multirow[t]{2}{*}{ India } & \multirow[t]{2}{*}{$\begin{array}{l}\text { Tungabhadra } \\
\text { project left } \\
\text { bank main } \\
\text { canal in } \\
\text { Tungabhadra } \\
\text { Project, South } \\
\text { West India }\end{array}$} & \multirow[t]{2}{*}{$\begin{array}{l}\text { 243,915 ha; } \\
87 \\
\text { distributaries }\end{array}$} & \multirow[t]{2}{*}{2004} & $\begin{array}{l}\text { Inefficient } \\
\text { use of water }\end{array}$ & & \multirow[t]{2}{*}{$\begin{array}{l}\text { Opportunity costs (forgone agricultural } \\
\text { income): Production losses (crop response } \\
\text { function to salt level plugged into crop } \\
\text { response function to water excess itself } \\
\text { plugged into profit function, modeling of } 4 \\
\text { scenarios. Crop response functions depend on } \\
\text { the levels of salinity and levels of water } \\
\text { applied) }\end{array}$} & $\begin{array}{l}\text { Profit loss because of } \\
\text { inefficient use of } \\
\text { irrigation water alone } \\
\text { (zero land } \\
\text { degradation) = IRs } \\
3.36 \text { billion/year } \\
\text { ( } 43 \% \text { of maximum } \\
\text { possible profit under } \\
\text { optimal water use = } \\
\text { IRs } 7.76 \text { billion/year }\end{array}$ & $\$ 74$ million/yr & \$91 million/yr \\
\hline & & & & & $\begin{array}{l}\text { Waterlogging } \\
\text { only }\end{array}$ & & & $\begin{array}{l}\text { Profit loss because of } \\
\text { waterlogging = IRs } \\
0.235 \text { billion/year } \\
\text { ( } 3 \% \text { of maximum } \\
\text { possible profit under } \\
\text { optimal water use = } \\
\text { IRs } 7.76 \text { billion/year) }\end{array}$ & $\$ 5$ million/yr & $\$ 6$ million/yr \\
\hline
\end{tabular}


Economics of Salt-induced Land Degradation and Restoration

\begin{tabular}{|c|c|c|c|c|c|c|c|c|c|}
\hline & & & & & $\begin{array}{l}\text { Waterlogging } \\
+ \text { salinity }\end{array}$ & & $\begin{array}{l}\text { Profit loss because of } \\
\text { waterlogging + } \\
\text { salinity = IRs } 1.70 \\
\text { billion/year ( } 29 \% \text { of } \\
\text { maximum possible } \\
\text { profit under } \\
\text { waterlogging + } \\
\text { salinity = IRs } 5.89 \\
\text { billion/year) }\end{array}$ & \$ 38 million/yr & \$ 46 million/yr \\
\hline $\begin{array}{l}\text { Madden et } \\
\text { al. (2000) }\end{array}$ & Australia & Australia & & 2000 & $\begin{array}{l}\text { Salinity } \\
\text { (majority) }\end{array}$ & $\begin{array}{l}\text { Mitigation behavior and replacement costs: } \\
\text { preventing and repairing land degradation in } \\
\text { Australia }\end{array}$ & $\begin{array}{l}\text { A } \$ 65 \text { billion over } 10 \\
\text { years (cited by } \\
\text { Pannell 2001) }\end{array}$ & $\$ 38$ billion/10 yr & $\$ 50$ billion/10 yr \\
\hline $\begin{array}{l}\text { Wilson } \\
\text { (2003) }\end{array}$ & Australia & $\begin{array}{l}\text { Murray- } \\
\text { Darling River } \\
\text { Basin }\end{array}$ & & 2003 & Salinity & $\begin{array}{l}\text { Opportunity costs (forgone agricultural } \\
\text { income) and Mitigation costs }\end{array}$ & $\begin{array}{l}\text { A } \$ 305 \text { million per } \\
\text { annum. This includes } \\
\text { costs to dryland } \\
\text { agricultural } \\
\text { producers (A } \$ 98 \\
\text { million) and costs to } \\
\text { households, } \\
\text { commerce and } \\
\text { industry (A } \$ 143 \\
\text { million), but } \\
\text { excludes the } \\
\text { additional costs of } \\
\text { salinity damage to } \\
\text { the environment and } \\
\text { cultural heritage }\end{array}$ & \$ 198 million/yr & \$ 249 million/yr \\
\hline $\begin{array}{l}\text { Marshall } \\
\text { (2004) }\end{array}$ & Australia & $\begin{array}{l}\text { Four adjoining } \\
\text { irrigation } \\
\text { districts in } \\
\text { New South } \\
\text { Wales } \\
\text { (Berriquin, } \\
\text { Denimein, } \\
\text { Wakool, } \\
\text { Cadell) in } \\
\text { Central Murray } \\
\text { region }\end{array}$ & $\begin{array}{l}\text { Farm area of } \\
749,202 \text { ha; } \\
\text { number of } \\
\text { farm } \\
\text { businesses } \\
\text { within the } \\
\text { schemes } \\
\text { estimated at } \\
1610 \\
\text { (Murray } \\
\text { Irrigation } \\
\text { Limited, } \\
\text { 1998) }\end{array}$ & 1995 & $\begin{array}{l}\text { Salinity and } \\
\text { waterlogging }\end{array}$ & $\begin{array}{l}\text { Transaction costs: Costs of developing and } \\
\text { implementing four land and water } \\
\text { management plans (LWMPs) }\end{array}$ & $\begin{array}{l}\text { Initially agreed } \\
\text { contributions of } \\
\text { \$A116 million from } \\
\text { NSW government } \\
\text { over the first } 15 \text { years } \\
\text { of implementation + } \\
\text { \$A58 million from } \\
\text { Commonwealth } \\
\text { government + \$A382 } \\
\text { million over 30 years } \\
\text { from cost-sharing } \\
\text { commitments of } \\
\text { landholders (in-kind } \\
\text { contributions + 'tax' } \\
\text { on water usage } \\
\text { \$A0.50-3.15/ML of }\end{array}$ & $\begin{array}{l}\text { Total } \\
\text { contribution of } \\
\$ 412 \text { million/30 } \\
\mathrm{yr}+\text { tax of } \\
\$ 0.37-2.34 / \mathrm{ML} \\
\text { of irrigation } \\
\text { entitlement }\end{array}$ & $\begin{array}{l}\text { Total } \\
\text { contribution of } \\
\$ 601 \text { million/30 } \\
\mathrm{yr}+\text { tax of } \\
\$ 0.54-3.41 / \mathrm{ML} \\
\text { of irrigation } \\
\text { entitlement }\end{array}$ \\
\hline
\end{tabular}


Qadir et al.

Economics of Salt-induced Land Degradation and Restoration

\begin{tabular}{|c|c|c|c|c|c|c|c|c|c|}
\hline & & & & & & & $\begin{array}{l}\text { irrigation } \\
\text { entitlement) }\end{array}$ & & \\
\hline $\begin{array}{l}\text { John et al. } \\
\text { (2005) }\end{array}$ & Australia & $\begin{array}{l}\text { Western } \\
\text { Australia with } \\
\text { average farm } \\
\text { size: } 3,750 \text { ha } \\
\text { (Australian } \\
\text { Bureau of } \\
\text { Statistics, } \\
\text { 2002) }\end{array}$ & & $\begin{array}{l}\text { Assumed } \\
2005\end{array}$ & $\begin{array}{l}\text { Severe } \\
\text { dryland } \\
\text { salinity } \\
\text { compared to } \\
\text { no dryland } \\
\text { salinity }\end{array}$ & $\begin{array}{l}\text { Opportunity cost (forgone agricultural } \\
\text { income): non-salinity specific whole farm } \\
\text { linear programming bio-economic model } \\
\text { called MUDAS (Model of an Uncertain } \\
\text { Dryland Agricultural System) developed and } \\
\text { augmented from what is described in Kingwell } \\
\text { (1994) and Kingwell et al. (1993) used to } \\
\text { estimate production losses because of more } \\
\text { limited cropping options on saline drylands }\end{array}$ & $\begin{array}{l}\text { A } \$ 65,000-94,000 \\
\text { profit loss because of } \\
\text { salinity (depending } \\
\text { on the impact of } \\
\text { climate change) }\end{array}$ & $\$ 71785$ & \$ 86054 \\
\hline $\begin{array}{l}\text { Aslam and } \\
\text { Prathapar } \\
\text { (2006) }\end{array}$ & Pakistan & Indus Basin & $\begin{array}{l}\text { Estimated } \\
\text { over a total } \\
\text { of } 2 \text { million } \\
\text { ha; annual } \\
\text { loss to } \\
\text { salinization } \\
\text { of } 28,000 \text { to } \\
40,000 \text { ha }\end{array}$ & $\begin{array}{l}\text { Assumed } \\
2006\end{array}$ & Salinity & $\begin{array}{l}\text { Not stated explicitly. Opportunity cost } \\
\text { (forgone agricultural income) }\end{array}$ & $\begin{array}{l}\text { Estimated } \$ 230 \\
\text { million/yr (PRs } \\
14,000 \text { million) }\end{array}$ & $\$ 230$ million/yr & \$ 267 million/yr \\
\hline \multirow[t]{2}{*}{$\begin{array}{l}\text { McCann } \\
\text { and } \\
\text { Hafdahl } \\
\text { (2007) }\end{array}$} & \multirow[t]{2}{*}{ Australia } & $\begin{array}{l}\text { Western } \\
\text { Australia }\end{array}$ & & $\begin{array}{l}\text { Cumulate } \\
\text { d value } \\
\text { over } \\
2003- \\
2007 \\
(2003 \\
\text { assumed } \\
\text { as year of } \\
\text { monetary } \\
\text { values) }\end{array}$ & Salinity & $\begin{array}{l}\text { Transaction costs: National Action Plan for } \\
\text { Salinity and Water Quality developed by the } \\
\text { Australian government }\end{array}$ & $\begin{array}{l}\text { A } \$ 125 \text { million } \\
\text { allocated to Western } \\
\text { Australia by } 2008\end{array}$ & \$ 81 million & \$ 102 million \\
\hline & & $\begin{array}{l}\text { Western } \\
\text { Australia, }\end{array}$ & $\begin{array}{l}73 \% \\
\text { response rate } \\
\text { in Western } \\
\text { Australia } \\
\text { over } 17 \\
\text { policies }\end{array}$ & 2007 & Salinity & $\begin{array}{l}\text { Transaction costs: National Action plan for } \\
\text { Salinity and Water Quality developed by the } \\
\text { Australian government }\end{array}$ & $\begin{array}{l}\text { Rating of perceived } \\
\text { farmer costs, farmer } \\
\text { resistance, perceived } \\
\text { administrative costs } \\
\text { and effectiveness of } \\
\text { salinity policies }\end{array}$ & & \\
\hline
\end{tabular}




\begin{tabular}{|c|c|c|c|c|c|c|c|c|c|c|}
\hline $\begin{array}{l}\text { Connor et } \\
\text { al. (2008) }\end{array}$ & Australia & $\begin{array}{l}\text { Bet Bet } \\
\text { catchment of } \\
\text { North Central } \\
\text { Victoria, a } \\
\text { relatively small } \\
\text { catchment in } \\
\text { the Murray } \\
\text { Darling Basin }\end{array}$ & $\begin{array}{l}\text { Approx. } \\
9600 \text { ha; } \\
\text { major source } \\
\text { of } 40,000 \mathrm{t} \\
\text { salt annually } \\
\text { entering } \\
\text { Boort } \\
\text { irrigation } \\
\text { area from } \\
\text { Loddon } \\
\text { dryland } \\
\text { catchment } \\
\text { area }\end{array}$ & $\begin{array}{l}10 \\
\text { periods, } \\
\text { assumed } \\
2004\end{array}$ & Salinity & & $\begin{array}{l}\text { Market prices: Groundwater recharge credits } \\
\text { trading; Experimental economics (closed and } \\
\text { open call market treatments. Closed call } \\
\text { market characterized by limited disclosure of } \\
\text { bidding information, restricted to market } \\
\text { prices and individual volumes traded, } \\
\text { excluding public disclosure of individual } \\
\text { bidding behavior. In contrast, open call } \\
\text { publicly declares (whilst maintaining } \\
\text { anonymity) all individual bidding and volume } \\
\text { offers) }\end{array}$ & $\begin{array}{l}\text { A } \$ 60-67 / M L \\
\text { recharge }\end{array}$ & $\begin{array}{l}\$ 44-49 / \mathrm{ML} \\
\text { recharge }\end{array}$ & $\begin{array}{l}\text { \$ 54-61/ML } \\
\text { recharge }\end{array}$ \\
\hline $\begin{array}{l}\text { Winpenny } \\
\text { et al. } \\
\text { (2010) }\end{array}$ & Spain & & & $\begin{array}{l}\text { Assumed } \\
2010\end{array}$ & $\begin{array}{l}\text { River } \\
\text { salinity }\end{array}$ & & $\begin{array}{l}\text { Mitigation costs: Desalination plant El Prat de } \\
\text { Llobregat, storage and pipelines }\end{array}$ & $\begin{array}{l}\text { Investment cost of } \\
\text { Euro } 578 \text { million }\end{array}$ & \$ 765 million & \$ 810 million \\
\hline \multicolumn{11}{|c|}{ Per unit area estimates } \\
\hline \multirow[t]{4}{*}{$\begin{array}{l}\text { Singh and } \\
\text { Singh } \\
\text { (1995) }\end{array}$} & \multirow[t]{4}{*}{ India } & \multirow{4}{*}{$\begin{array}{l}\text { Western } \\
\text { Jamuda Canal } \\
\text { (251,000 ha) } \\
\text { and Bhakra } \\
\text { Canal (102,000 } \\
\text { ha) in Haryana }\end{array}$} & \multirow{4}{*}{$\begin{array}{l}\text { Stratified } \\
\text { sampling; } \\
248 \\
\text { respondents } \\
\text { (114 normal } \\
\text { farms +138 } \\
\text { problem- } \\
\text { affected } \\
\text { farms) }\end{array}$} & \multirow[t]{4}{*}{$\begin{array}{l}1989- \\
1990 \\
\text { cropping } \\
\text { season }\end{array}$} & \multirow[t]{4}{*}{ Salinity } & Rice & \multirow{4}{*}{$\begin{array}{l}\text { Opportunity costs (forgone agricultural } \\
\text { income): computation of profit from normal } \\
\text { soils minus profit from degraded soils) } \\
\text { Cobb-Douglas function to study determinants } \\
\text { of outputs and profits for different soils types } \\
\text { (dose response method) }\end{array}$} & $\begin{array}{l}\text { Loss of gross income } \\
\text { because of } \\
\text { salinisation: IRs } \\
\text { 3107/ha }\end{array}$ & $\$-184 / \mathrm{ha} / \mathrm{yr}$ & \$ 313/ha/yr \\
\hline & & & & & & Wheat & & $\begin{array}{l}\text { Loss of gross } \\
\text { income: IRs 2366/ha }\end{array}$ & $\$ 140 / \mathrm{ha} / \mathrm{yr}$ & \$ 238/ha/yr \\
\hline & & & & & & Cotton & & $\begin{array}{l}\text { Loss of gross } \\
\text { income: IRs 4335/ha }\end{array}$ & \$ 257/ha/yr & $\$ 437 / \mathrm{ha} / \mathrm{yr}$ \\
\hline & & & & & & $\begin{array}{l}\text { Sugarca } \\
\text { ne }\end{array}$ & & $\begin{array}{l}\text { Loss of gross } \\
\text { income: IRs 2982/ha }\end{array}$ & $\$ 177 / \mathrm{ha} / \mathrm{yr}$ & \$ 300/ha/yr \\
\hline \multirow[t]{2}{*}{$\begin{array}{l}\text { World } \\
\text { Bank } \\
\text { (1998) }\end{array}$} & \multirow[t]{2}{*}{$\begin{array}{l}\text { Central } \\
\text { Asia } \\
\text { region }\end{array}$} & \multirow{2}{*}{$\begin{array}{l}\text { Aral Sea Basin } \\
\text { (Amu-Darya } \\
\text { and Syr-Darya } \\
\text { River Basins) } \\
\text { in Kazakhstan, } \\
\text { Kyrgyz } \\
\text { Republic, } \\
\text { Tajikistan, } \\
\text { Turkmenistan, } \\
\text { and Uzbekistan }\end{array}$} & & \multirow[t]{2}{*}{$\begin{array}{l}\text { Assumed } \\
1998\end{array}$} & \multirow[t]{2}{*}{ Salinity } & & $\begin{array}{l}\text { Opportunity costs (no details on } \\
\text { computations) }\end{array}$ & $\begin{array}{l}\text { \$250/ha/year; } \$ 2 \\
\text { billion/year (about } 5 \\
\text { per cent of Central } \\
\text { Asia's GNP) }\end{array}$ & $\begin{array}{l}\text { \$250/ha/yr; } \\
\text { \$2billion/yr }\end{array}$ & $\begin{array}{l}\text { \$344/ha/yr; } \\
\$ 2.7 \text { billion/yr }\end{array}$ \\
\hline & & & & & & & $\begin{array}{l}\text { Replacement costs (no details on } \\
\text { computations) }\end{array}$ & $\begin{array}{l}\text { Rehabilitation and } \\
\text { improvement costs of } \\
\text { irrigated land may } \\
\text { range from } \$ 2000 / \mathrm{ha} \\
\text { to } \$ 4500 / \mathrm{ha}\end{array}$ & \$ 2000-4500/ha & \$ 2750-6187/ ha \\
\hline
\end{tabular}




\begin{tabular}{|c|c|c|c|c|c|c|c|c|c|c|}
\hline $\begin{array}{l}\text { Houk et al. } \\
\text { (2006) }\end{array}$ & $\begin{array}{l}\text { United } \\
\text { States }\end{array}$ & $\begin{array}{l}\text { Arkansas } \\
\text { Basin }\end{array}$ & $\begin{array}{l}65,000 \\
\text { irrigated } \\
\text { acres over } \\
3000 \\
\text { different } \\
\text { fields }\end{array}$ & 2006 & $\begin{array}{l}\text { Salinity and } \\
\text { waterlogging }\end{array}$ & & $\begin{array}{l}\text { Dose-response method: production losses } \\
\text { (relative yield factor * potential yield = } \\
\text { relative yield associated with soil salinity * } \\
\text { relative yield associated with water logging * } \\
\text { potential yield) associated with detailed } \\
\text { hydrological model }\end{array}$ & $\begin{array}{l}\text { Average: } \$ 68 / \text { ha } \\
\text { (\$83.34/ha in } 1999 \text {, } \\
\$ 50.05 / \text { ha in } 2000 \text {, } \\
\$ 70.90 / \text { ha in } 2001)\end{array}$ & $\$ 68 / \mathrm{ha}$ & \$79/ha \\
\hline \multirow[t]{2}{*}{$\begin{array}{l}\text { Lowell et } \\
\text { al. (2007) }\end{array}$} & \multirow[t]{2}{*}{ Australia } & $\begin{array}{l}\text { Gippsland, } \\
\text { Southwestern } \\
\text { Victoria (2 } \\
\text { million ha) }\end{array}$ & 127 ha & 2004 & $\begin{array}{l}\text { Sodicity } \\
\text { (limited } \\
\text { extent) }\end{array}$ & & \multirow{2}{*}{$\begin{array}{l}\text { Mitigation behavior (costs of action): cost } \\
\text { (bid) of establishing tree plantations from } \\
\text { landowners, and quantitative hydrological } \\
\text { model to estimate salinity benefit (amount of } \\
\text { land that would have become sodic had the } \\
\text { trees not been planted) }\end{array}$} & $\mathrm{A} \$ 0 / \mathrm{ha}$ & $\$ 0 /$ ha & \\
\hline & & $\begin{array}{l}\text { Boundaries of } \\
\text { the Coragamite } \\
\text { Catchment } \\
\text { Management } \\
\text { Authority in } \\
\text { south western } \\
\text { Victoria (1.3 } \\
\text { million ha) }\end{array}$ & 654 ha & 2004 & $\begin{array}{l}\begin{array}{l}\text { Sodicity } \\
\text { (more } \\
\text { widespread) }\end{array} \\
\end{array}$ & & & A\$5020/ha & \$ 3692/ha & \$ 4550/ha \\
\hline \multirow[t]{2}{*}{$\begin{array}{l}\text { Wicke et } \\
\text { al. (2011) }\end{array}$} & \multirow[t]{2}{*}{ Global } & Global & Global & 2010 & Salinity & & Market prices: Land rents & $\begin{array}{l}\text { Land rents ranging } \\
\text { from Euro } 7 \text { /ha/yr in } \\
\text { East Africa to } 247 \\
\text { Euro/ha/yr in Japan }\end{array}$ & $\begin{array}{l}\text { Land rents } \\
\text { ranging from } \\
\text { \$9/ha/yr in East } \\
\text { Africa to \$ } \\
\text { 327/ha/yr in } \\
\text { Japan }\end{array}$ & $\begin{array}{l}\text { Land rents } \\
\text { ranging from } \\
\text { \$10/ha/yr in East } \\
\text { Africa to } \\
\text { \$347/ha/yr in } \\
\text { Japan }\end{array}$ \\
\hline & & Global & Global & 2010 & Salinity & Forestry & $\begin{array}{l}\text { Opportunity costs (alternative activities): } \\
\text { scenario parameters to estimate the biosaline } \\
\text { forestry (the 'second-best' crop) production } \\
\text { costs for energy production (i.e. the } \\
\text { opportunity cost of still cropping the land for } \\
\text { food production) }\end{array}$ & $\begin{array}{l}\text { Biosaline forestry } \\
\text { production costs are } \\
\text { either } 2 \text { Euro per } \\
\text { Giga Joule or } 5 \text { Euro } \\
\text { per Giga Joule }\end{array}$ & \$ 3-7/Giga Joule & \$ 3-7/Giga Joule \\
\hline
\end{tabular}

${ }^{a}$ Unless otherwise specified, \$ refers to 2013 US dollars (US\$) throughout this publication. 2013 values were computed by applying the exchange rate for a specific currency to obtain the US\$ equivalent in the year of estimation, then adjusted for US\$ inflation using GDP deflator (annual \%). Based on World Bank and OECD Data available at:

http://stats.oecd.org/Index.aspx?QueryId=169\# and http://databank.worldbank.org/data/views/reports/tableview.aspx [accessed: 24 July 2013], then corrected for inflation to obtain the 2013 equivalent \$ amount (http://databank.worldbank.org/data/views/reports/tableview.aspx [accessed: 24 July 2013] 
Table 2 Comparative evaluation of crop yields from salt-affected and non-affected (normal) lands in the Indo-Gangetic Basin in India (Based on the data from Tripathi, 2009)

\begin{tabular}{|l|c|c|c|}
\hline \multirow{2}{*}{ Crop } & \multicolumn{2}{|c|}{ Crop yield $\left(\mathrm{t} \mathrm{ha}^{-1}\right)$} & Yield loss $^{a}$ \\
\cline { 2 - 4 } & Normal land & Salt-affected land & $(\%)$ \\
\hline Rice & 3.99 & 2.18 & 45 \\
\hline Wheat & 2.59 & 1.57 & 40 \\
\hline Cotton & 1.63 & 0.61 & 63 \\
\hline Sugarcane & 63.68 & 33.02 & 41 \\
\hline
\end{tabular}

${ }^{a}$ Figures presented under this column indicate percentage yield loss in salt-affected land over non-affected (normal) lands. 
Table 3 Summary statistics of soil properties (Electrical conductivity, EC; and sodium adsorption ratio, SAR) and resulting economics of action versus no action expressed in terms of net income from 8 salt-affected field sites and corresponding 8 ameliorated field sites in the Indus Basin in Pakistan (Based on the data from Murtaza, 2013)

\begin{tabular}{|c|c|c|c|c|c|c|c|c|c|}
\hline \multicolumn{10}{|c|}{ Summary statistics (Mean, minimum, and maximum values; and standard deviation, SD) } \\
\hline \multirow[t]{2}{*}{ Crop } & \multirow[t]{2}{*}{ Statistics } & \multicolumn{2}{|c|}{ EC $\left(\mathrm{dS} \mathrm{m} \mathrm{m}^{-1}\right)$} & \multicolumn{2}{|c|}{ SAR } & \multicolumn{2}{|c|}{ Income (\$) } & \multirow{2}{*}{$\begin{array}{c}\operatorname{Loss}^{c} \\
(\$)\end{array}$} & \multirow{2}{*}{$\begin{array}{l}\text { Reduction } \\
\text { (\%) }\end{array}$} \\
\hline & & $\mathrm{SAL}^{a}$ & $\mathrm{AML}^{b}$ & SAL & AML & SAL & AML & & \\
\hline \multirow{4}{*}{ Rice } & Mean $^{d}$ & 8.8 & 3.3 & 35.0 & 11.1 & 427 & 825 & 398 & 48.2 \\
\hline & Minimum & 6.0 & 3.0 & 25.0 & 9.7 & 93 & 175 & 82 & 36.1 \\
\hline & Maximum & 12.5 & 3.9 & 44.5 & 12.5 & 720 & 1220 & 724 & 69.2 \\
\hline & SD & 2.5 & 0.3 & 6.2 & 1.2 & 239 & 406 & 220 & 10.9 \\
\hline \multirow{4}{*}{ Wheat } & Mean & 6.5 & 3.4 & 23.5 & 10.9 & 771 & 1115 & 344 & 31.5 \\
\hline & Minimum & 4.7 & 2.9 & 19.1 & 9.8 & 185 & 304 & 119 & 20.2 \\
\hline & Maximum & 9.2 & 3.9 & 26.1 & 12.0 & 1134 & 1583 & 597 & 42.7 \\
\hline & SD & 1.4 & 0.3 & 2.8 & 0.8 & 329 & 461 & 181 & 9.6 \\
\hline
\end{tabular}

Correlation of EC and SAR with income parameters and significance in terms of $p$-value given in parentheses

\begin{tabular}{|c|c|c|c|c|c|}
\hline Crop & Land type & Soil parameter & Income & Loss & Reduction (\%) \\
\hline \multirow{4}{*}{ Rice } & \multirow{2}{*}{ SAL } & EC & $0.61(0.11)$ & $0.066(0.88)$ & $-0.49(0.22)$ \\
\hline & & SAR & $-0.28(0.50)$ & $0.36(0.38)$ & $0.70(0.054)$ \\
\hline & \multirow{2}{*}{ AML } & EC & $-0.75(0.033)$ & $-0.80(0.018)$ & $-0.34(0.41)$ \\
\hline & & SAR & $-0.58(0.13)$ & $-0.18(0.66)$ & $0.60(0.12)$ \\
\hline \multirow{4}{*}{ Wheat } & \multirow{2}{*}{ SAL } & EC & $0.70(0.052)$ & $0.39(0.34)$ & $-0.35(0.40)$ \\
\hline & & SAR & $-0.29(0.48)$ & $-0.15(0.72)$ & $0.20(0.63)$ \\
\hline & \multirow{2}{*}{ AML } & EC & $0.24(0.56)$ & $0.43(0.29)$ & $0.53(0.17)$ \\
\hline & & SAR & $0.41(0.31)$ & $0.19(0.65)$ & $-0.24(0.60)$ \\
\hline
\end{tabular}

${ }^{a}$ SAL: Salt-affected land

${ }^{b}$ AML: Ameliorated land

${ }^{c}$ Loss of net income in salt-affected land when compared to the ameliorated land

${ }^{d}$ Means under SAL and EC were significantly different $(p<0.05)$ except for wheat for income; $p$ value referred to probability of observing a correlation larger than observed when the correlation in the population is zero 
Table 4 Economics of action versus no action for salt-affected lands by using cost-benefit analysis of adopting different best-bet practices versus control with no action (Based on the data from Hassan et al., 2013)

\begin{tabular}{|c|c|c|c|c|c|c|c|c|c|c|c|c|}
\hline \multirow[t]{2}{*}{ Treatment } & \multicolumn{9}{|c|}{ Cost $\left(\$\right.$ ha $\left.^{-1}\right)$} & \multirow{2}{*}{$\begin{array}{l}\text { Wheat yield } \\
\left(\mathrm{kg} \mathrm{ha}^{-1}\right)\end{array}$} & \multicolumn{2}{|c|}{ Benefit $\left(\$ h a^{-1}\right)$} \\
\hline & $\begin{array}{c}\text { Land } \\
\text { preparation }\end{array}$ & Seed & Fertilizer $^{a}$ & Herbicide $^{b}$ & Irrigation & Harvest & Miscellaneous & Practice $^{c}$ & Total & & Income & Profit \\
\hline Deep plowing & 300 & 60 & 330 & 150 & 160 & 80 & 50 & 40 & 1220 & 2800 & 1866 & 646 \\
\hline $\begin{array}{l}\text { Control (for } \\
\text { deep plowing) }\end{array}$ & 350 & 60 & 150 & - & 160 & 80 & 50 & - & 800 & 1600 & 1066 & 266 \\
\hline Crop rotation $^{d}$ & 450 & 80 & 360 & 150 & 220 & 120 & 70 & - & 1490 & $\begin{array}{l}\text { Wheat: } 3600 \\
\text { Mung bean: } 1600\end{array}$ & 3733 & 2243 \\
\hline $\begin{array}{l}\text { Control (for } \\
\text { crop rotation) }\end{array}$ & 300 & 60 & 150 & - & 160 & 80 & 50 & - & 800 & 1600 & 1066 & 266 \\
\hline Mixing residue & 350 & 120 & 330 & 150 & 160 & 80 & 50 & - & 1340 & 3600 & 2397 & 1057 \\
\hline $\begin{array}{l}\text { Control (for } \\
\text { mixing residue) }\end{array}$ & 300 & 120 & 150 & - & 160 & 80 & 50 & - & 860 & 2500 & 1665 & 805 \\
\hline Digging drain & 350 & 60 & 330 & 150 & 160 & 80 & 50 & 25 & 1205 & 3600 & 2398 & 1193 \\
\hline $\begin{array}{l}\text { Control (for } \\
\text { digging drain) }\end{array}$ & 300 & 60 & 150 & - & 160 & 80 & 50 & - & 800 & 1600 & 1066 & 266 \\
\hline
\end{tabular}

${ }^{a}$ Farmers applied higher amount of fertilizer when adopting a best-bet practice because the risk of crop failure due to salinity was lower compared to control

${ }^{b}$ Farmers applied herbicides when the risk of crop failure due to salinity was lower compared to control

${ }^{c}$ Practice implies the best-bet practice (respective treatment)

${ }^{d}$ Wheat - Mung bean crop rotation 


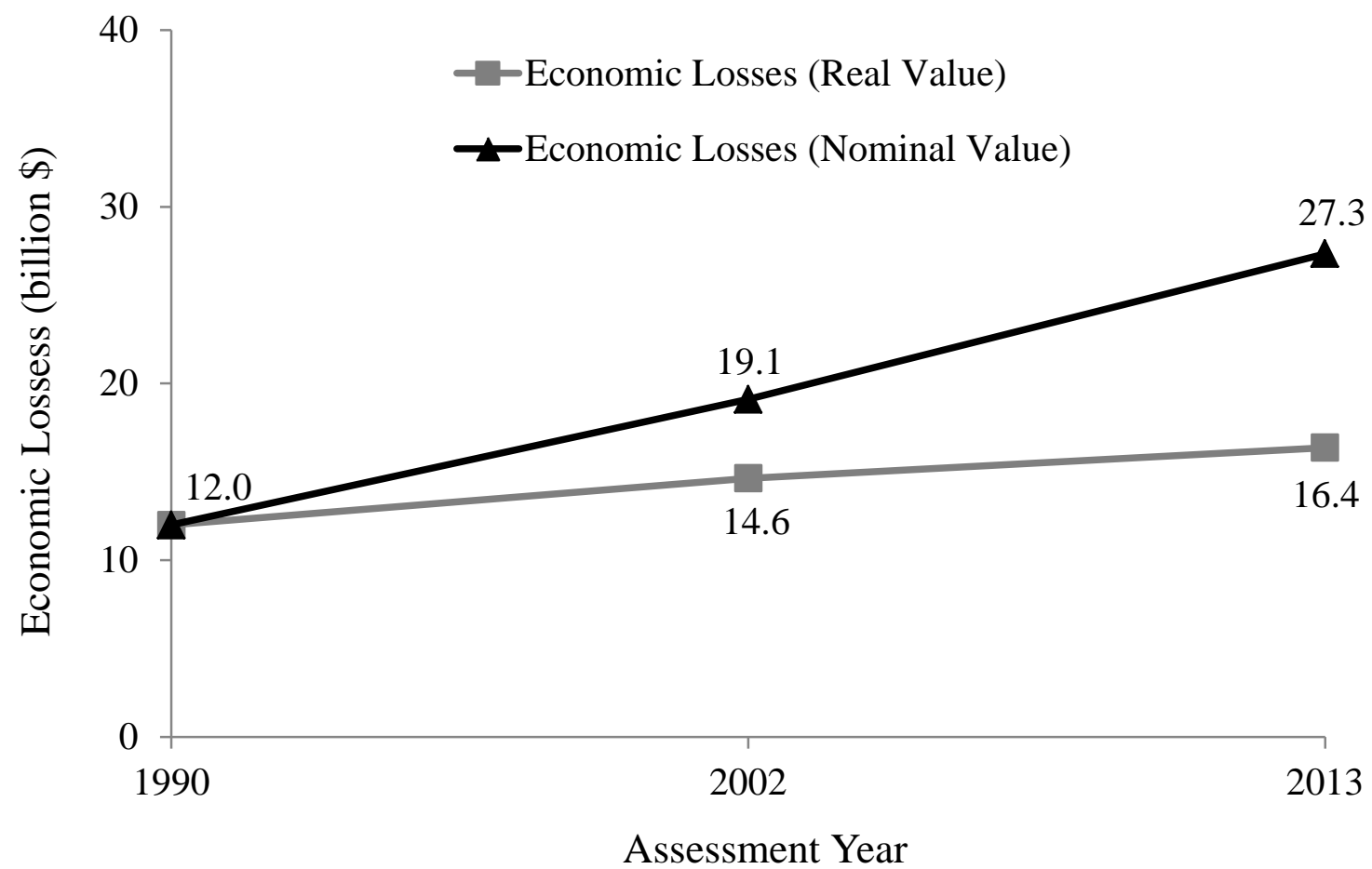

Figure 1 Economic cost of salt-induced land degradation in irrigated areas of the world. The estimates from 1990 are based on the data from Ghassemi et al. (1995) while estimates for the year 2002 and 2013 are based on the extent of saltaffected land in irrigated area. Real value refers to economic losses based on the 1990 cost per ha while nominal value refers to the economic losses in 1990 translated into their equivalent amount in 2002 and 2013 by adding inflation. 


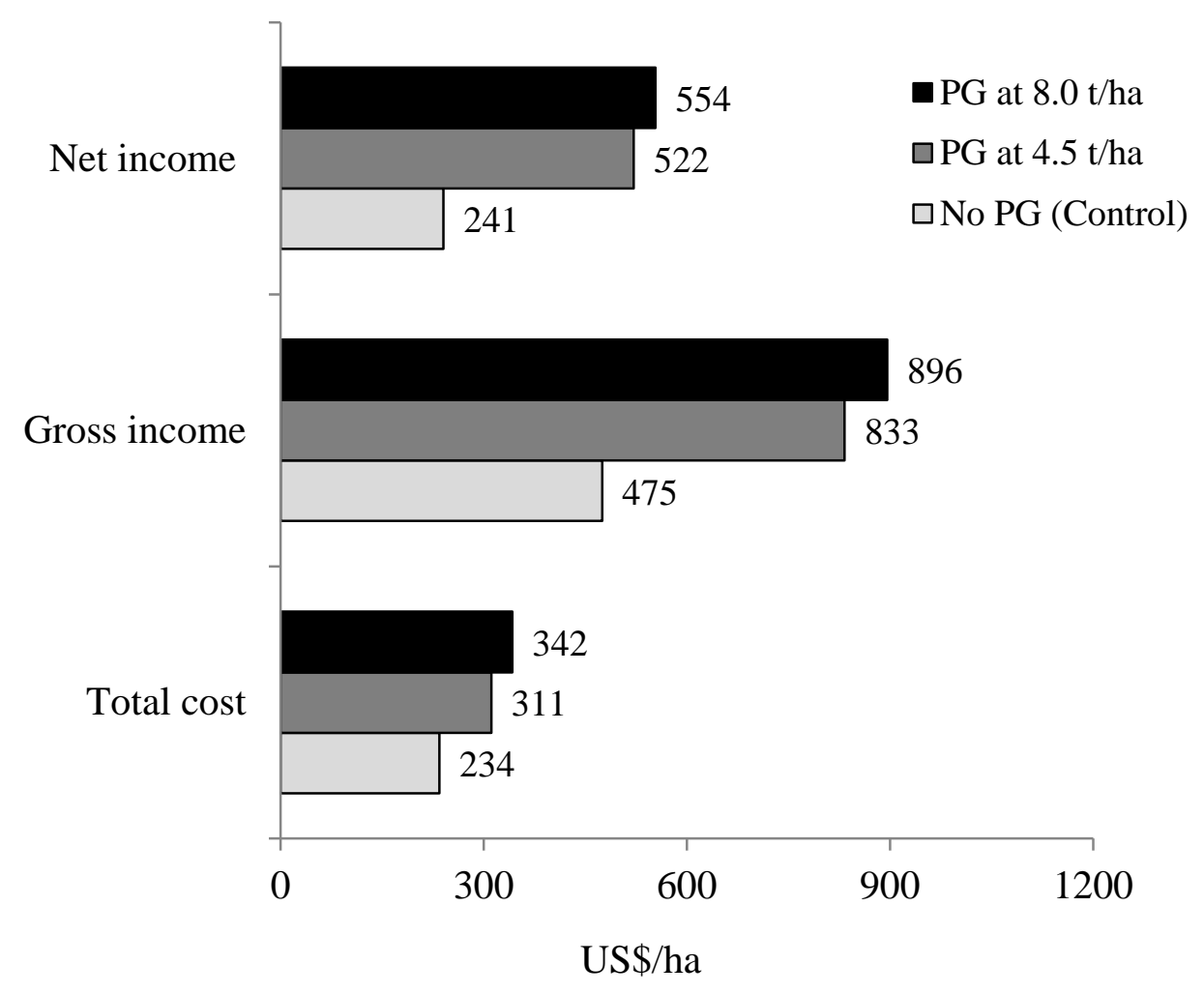

Figure 2 Total cost, gross income, and net income reflecting on the economics of 'no action' and 'action' under control and phosphogypsum treatments, respectively. The cost and income determined in local currency (Kazakh Tenge) were converted to US\$ with the currency exchange rate in the respective years (Based on the data from Vyshpolsky et al., 2008). 